\title{
Imidazole Antifungals: A Review of Their Action Mechanisms on Cancerous Cells
}

\author{
Berna Kavakcıŏglu Yardımcı 1 1,*
}

${ }^{1}$ Department of Chemistry, Faculty of Science and Art, Pamukkale University, Denizli, Turkey

\begin{abstract}
Imidazoles, together with triazoles, constitute azole sub-group of antifungal drugs which acts by inhibiting cytochrome P450-dependent enzyme, the lanosterol 14- $\alpha$-demethylase. In addition to their primary use, when it comes to additional anti-cancer function, clotrimazole, econazole and ketoconazole have come to the fore among the imidazoles. Based on the findings up to now, although having different effects, disruption of the glycolytic pathway, blockage of $\mathrm{Ca}^{2+}$ influx and nonspecific inhibition of CYP450 enzymes can be regarded as the main ones responsible for the antineoplastic activities of the mentioned drugs, respectively. Considering the advantages of repurposing of drugs with known pharmacology compared to new drug development studies requiring labor, time and cost, it will be extremely important and valuable to continue the clarification of the different mechanisms of these antifungals on cancerous cells and benefit from them especially to increase drug efficacy and overcome drug resistance. In this review, the action mechanisms of imidazole antifungals on cancerous cells and consequently, their potential for use in cancer treatment alone or in combination with conventional therapeutics were discussed in detail.
\end{abstract}

\section{ARTICLE HISTORY}

Received: April 03, 2020

Revised: May 07, 2020

Accepted: May 29, 2020

\section{KEYWORDS}

Imidazole Antifungals, Clotrimazole,

Econazole,

Ketoconazole,

Cancer

\section{INTRODUCTION}

As their names imply, antifungal drug is an agent which selectively kills fungal pathogens with minimal toxicity to the host and antifungal/antimitotic medication is to use these agents to treat and/or prevent serious systemic fungal infections [1]. According to their mode of action, there are seven known classes of antifungals including targeting ergosterol biosynthesis, fungal cell wall synthesis, sphingolipids biosynthesis, nucleic acid synthesis, protein biosynthesis, microtubules biosynthesis and disrupting fungal membrane. The antifungal class which acts by targeting biosynthesis of ergosterol, one of the main constituent of membranes, is called azoles. To put it more clearly, the azole class of antifungal drugs inhibits cytochrome P450 (CYP450)dependent enzyme, the lanosterol 14- $\alpha$-demethylase [2]. The inhibition of the so-called enzyme induces both the ergosterol consumption and sterol accumulation, the situation of which leads to loss of many functions of fungal membrane and afterwards fungal growth [3]. Various azoles have been used effectively for more than 35 years on the management of invasive fungal infections caused by the strains such as dermatophytes and Candida spp. Among the azoles, the

CONTACT: Berna Kavakcıoğlu Yardımcı $\bowtie$ byardimci@pau.edu.tr $\risingdotseq$ Department of Chemistry, Faculty of Science and Art, Pamukkale University, Denizli, Turkey 
imidazoles are the first developed ones, the usages of which were limited for superficial mycoses, the fungal infections invading the most superficial layer of the epidermis, because of gastrointestinal intolerability and neurologic adverse effects at high doses besides their low solubility in physiological solutions. However, triazoles were developed to meet a broad range of treatments and new-generation azole antifungals are under trial for more efficient medication, minimum side effects and, of course, ease of administration [4]. On the other hand, it should be emphasized that there has been also promising researches on using imidazoles against cancer besides their primary uses. From this point of view, it was aimed to collect the results of the studies, from past to present, assessing the effects of imidazoles on various cancerous cell or tissue types to make a general conclusion about the possible potentials of these antifungals in the treatment of cancer.

\subsection{Imidazoles}

Imidazole antifungal drugs have two atoms of nitrogen in their azole rings. Bifonazole, butoconazole, clotrimazole, ketoconazole, econazole, fenticonazole, isoconazole, miconazole and oxiconazole are some of the examples of this azole class. According to the literature survey, it can be clearly seen that among these imidazoles, clotrimazole (CTZ), econazole (ENZ) and ketoconazole (KTZ) are the most hitherto investigated ones for their potentials in cancer treatment.

\subsubsection{Clotrimazole}

CTZ (1-[(2-chlorophenyl)-diphenylmethyl]imidazole) has been known as a broad spectrum antimycotic or antifungal agent since its introduction to German markets in 1973 [5, 6]. It has long been known that the drug is effective on the strains of Trichophyton rubrum, Trichophyton mentagrophytes, Epidermophyton floccosum, Candida albicans and Malassezia furfur [7]. Apart from its routine antifungal function, through the studies trying to reveal the direct anti-inflammatory properties of the azole derivatives, CTZ was recognized as one of the antifungals having ability to antagonize calmodulin $(\mathrm{CaM})$ activity with the $\mathrm{IC}_{50}$ value of $18.4 \pm 4.6 \mu \mathrm{M}$, which was shown based on the inhibition of CaM-dependent phosphodiesterase (PDE) [8]. $\mathrm{CaM}$ is multifunctional intermediate calcium $\left(\mathrm{Ca}^{2+}\right)$-binding messenger protein expressed in all eukaryotic cells [9] and so its antagonists play significant roles in many cellular processes [10]. It is not wrong to say that, with the discovery of $\mathrm{CaM}$ antagonist function, possible anticancer effects of CTZ started to be investigated. As known, the primary energy source of cancer cells is glycolysis that is controlled by allosteric regulators and by reversible attachment of the glycolytic enzymes to cytoskeleton and mitochondria [11-19]. Due to $\mathrm{Ca}^{2+}$ ions have impact on the increase of glycolytic enzyme attachment; CTZ could be an effective agent for inhibition of glycolysis. Indeed, the studies to date have indicated that CTZ shows its main action on cancerous cells by disrupting the glycolytic pathway (Table 1). According to literature survey, the primary study introducing the inhibition effect of CTZ on cell proliferation was conducted by Benzaquen and her group in 1995 [20]. In the so-called paper, it was stated that $10 \mu \mathrm{M}$ CTZ completely inhibited growth factor-stimulated proliferation of Albino Swiss mouse embryo fibroblasts 3T3 (Swiss 3T3), bovine aortic endothelial cells (BAEC) and rat aortic smooth muscle (RASM) cells besides several human and mice cancers including lung, colon and melanoma with no apparent toxicity. The researchers based this anti-proliferative effect of CTZ on inhibition of $\mathrm{Ca}^{2+}$ movement across the plasma membrane but they did not investigate the possible alterations in glycolytic pathway. On the other hand, in the research conducted on B16 melanoma cells, it was firstly found that CTZ $(5-50 \mu \mathrm{M})$ significantly reduced the levels of glucose 1,6-bisphosphate, fructose 1,6-bisphosphate and ATP, in a dose dependent manner within $1 \mathrm{~h}$ [21]. Following these findings, in other two studies carried out under the same conditions and with the same cell line, CTZ was shown to induce detachment of phosphofructokinase and aldolase from cytoskeleton, and hexokinase from mitochondria in 
a dose dependent manner, which made this antifungal promising agent in treatment of melanoma [22, 23]. Afterwards, the disruptive effect of $0-500 \mu \mathrm{M} \mathrm{CTZ}$ on glycolytic pathway within 0-48 h was determined for various cancer cell lines including breast, kidney, lung, colon, glioblastoma and ovarian cancers [24-28]. In addition, it should be stated that CTZ induced detachment of glycolytic enzymes preceded the cell death that generally based on apoptosis. As is very well known, apoptosis is one of the programmed cell death types and it is intended to eliminate cancer cells by primarily this death pathway. Studies carried out until now have shown that CTZ induced apoptotic death in various cancer cell lines, characterized by phosphatidylserine externalization, DNA fragmentation, induction in cell-cycle arrest in G1and $\mathrm{M}$ - phases, release of pro-apoptotic factor cytochrome $\mathrm{c}$ into the cytoplasm, downregulation of the anti-apoptotic Bcl-2 protein, increase in pro-apoptotic Bax protein levels and induction in wild type p53 levels [26, 29-32]. Furthermore, maybe it could be supportive to state that CTZ significantly induced the activity of metacaspase Yca1, structural homolog to apoptotic human caspases, in yeast model organism [33]. Finally, it was demonstrated in a limited number of studies that some derivatives of CTZ or its combination with antineoplastic drugs exhibited more cytotoxicity on cancerous cells than its individual application $[32,34,35]$.

Table 1. Action mode of clotrimazole-induced death on several cell lines and tissues

\begin{tabular}{lcc}
\hline \multicolumn{1}{c}{ Mode of Action } & Cell/Tissue Type & References \\
\hline $\begin{array}{l}\text { Inhibition of growth factor stimulated cell } \\
\text { growth, }\end{array}$ & albino swiss mouse embryo fibroblast & cell line (Swiss 3T3), bovine aortic \\
Blockage in mitogen-induced intracellular & endothelial cell line, rat aortic smooth & [20] \\
Ca2+ increase in Swiss 3T3 cells, & muscle cell line, human lung and colon & \\
$\begin{array}{l}\text { Depletion in intracellular Ca2+ stores in Swiss } \\
\text { 3T3 cells }\end{array}$ & $\begin{array}{c}\text { carcinomas, human and mice melanoma } \\
\text { cells }\end{array}$ \\
\hline
\end{tabular}

Decrease in the levels of glucose 1,6-

bisphosphate, fructose 1,6-bisphosphate and

ATP in a dose and time dependent manner,

Detachment of phosphofructokinase and

aldolase from cytoskeleton in a dose and time

mouse melanoma cell line

dependent manner,

Detachment of hexokinase from mitochondria

in a dose dependent manner

Inhibition of basal and growth factor stimulated

vascular endothelial cell proliferation in a dose

dependent and non-toxic manner,

Inhibition of the basal and bFGF-stimulated

migration of bovine capillary endothelial cells,

Inhibition of the angiogenesis both in vitro and

human, bovine and porcine vascular

endothelial cells stimulated with vascular

endothelial growth factor (VEGF) and

basic fibroblast growth factor (bFGF),

in vivo models

At higher doses $(50-70 \mu \mathrm{M})$

Inhibition of cell growth in a dose-dependent

and toxic manner

At lower doses $(0-30 \mu \mathrm{M})$

Inhibition of cell growth in a dose-dependent

and non-toxic manner,

Formation of small retracted cell bodies and

thin elongated cytoplasmic processes,

Cell cycle arrest at G0/G1 phase,

Increase in p53 and glial fibrillary acidic

protein (GFAP) expressions,

Decrease in cellular c-myc and c-fos

expression,

bFGF-injected male C57B16 mice

Sensitization to antitumor effect of cisplatin

human glioblastoma cells (with wild or mutant types $\mathrm{p53}$ ) 
Suppression of cell recovery in a dose dependent manner,

Cytotoxicity even against cells with multidrugresistant phenotype and carrying genetic abnormalities,

Depletion of intracellular $\mathrm{Ca} 2+$ stores,

human B- and T-lineages acute

lymphoblastic leukemia (ALL) cell lines and human primary ALL cells

Apoptosis shown by Annexin V binding reactivity and induction of DNA fragmentation

Decrease in the levels of glucose 1,6bisphosphate and fructose 1,6-bisphosphate in a dose- and time-dependent manner,

Reduction in ATP levels and time-dependent reduction in the viability,

murine lewis lung carcinoma cell line, murine colon adenocarcinoma cell line

Alteration in cytosolic ion concentrations,

Induction of necrotic morphological changes

Decrease in cell viability in a dose- and time-

dependent manner,

Induction in morphological and functional

alterations including nuclear condensation and loss of protrusion,

Detachment of 6-phosphofructo-1-kinase and

human breast cancer cell line

aldolase from cytoskeleton,

Decrease in glucose consumption and lactate

production rates

Cell cycle arrest at the G1 phase in a dose- and

time-dependent manner,

Overexpression of p27Kip and decreased

expression of p21Cip, cyclin-dependent kinase

1 , cyclin-dependent kinase 4 , and cyclin D,

Translocation of mitochondrial-bound

human glioblastoma cell line

hexokinase II to the cytoplasm,

Release of cytochrome c into the cytoplasm,

Sensitization to radiation-induced apoptosis

evidenced by Annexin V-FITC staining

Reduction in lactate production,

Inhibition in phosphofructokinase activity,

In vitro dissociation of phosphofructokinase

human breast cancer tissue

from f-actin

Inhibition of migration in an aggressiveness

dependent manner,

Decrease in cell proliferation,

Decrease in cell viability in an aggressiveness-

dependent manner,

Dose- and aggressiveness-dependent reduction

in glucose uptake and mitochondrial activity,

Decrease in cellular ATP levels in a dose

dependent manner,

Inhibition in hexokinase, phosphofructokinase-

1 , pyruvate kinase and glucose 6-phosphate

dehydrogenase activities,

Decrease in cell viability in an aggressiveness-

dependent manner

Inhibition of cell viability in a dose- and time-

dependent manner,

Decrease in cell colony formation in a dose-

dependent manner,

Cell cycle arrest at the G0/G1 phase in a dose-

dependent manner,

Induction of apoptosis showed by Annexin

V/PI staining in a dose-dependent manner,

human breast cancer cells (with different aggressiveness profiles) 
Down- and up-regulations of the anti-apoptotic Bcl-2 and the pro-apoptotic Bax proteins, respectively both in vitro and in vivo models, Decrease in in vivo tumor volume and proliferation rate,

Induction of apoptosis in in vivo model showed by cleaved caspase-3 expression

Reduction in cell viability in a dose-dependent manner,

Induction of mainly early stage apoptosis showed by Annexin V/7-AAD staining, Induction of internucleosomal DNA fragmentation and accumulation of histonecomplexed DNA fragments in the cytoplasmic fraction,

Absence of histone-complexed DNA fragments human cutaneous melanoma cell line human oral squamous cell carcinoma (OSCC) cells, OSCC xenograft nude mouse model in the culture supernatant (the evidence of cell death without any involvement of necrosis), Induction of cell-cycle arrest at G1/S phase transition,

Reduction in the expression and activity of hexokinase type-II

When combined with romidepsin (RDP) or belinostat (BNS), increased sensitivity to apoptosis showed by Annexin V-SYTOX staining,

Requirement of caspase- 3 activation and, Bak and Bax expression for RDP plus CLT induced apoptosis,

Decrease in total hexokinase 2 (HK2) levels

and decreased HK2 expression on the

mitochondria after treatment with CLT

\subsubsection{Econazole}

Another imidazole that has exhibited a remarkable effect on cancer cells is ENZ (1-[2[(4-chlorophenyl)methoxy]-2-(2,4-dichlorophenyl)ethyl]imidazole). This antifungal is widely used in the treatments of vulvovaginal candidiasis, superficial fungal infection, keratitis and athlete's foot [36-39]. Early findings about the other functions of this agent revealed that it inhibited lipopolysaccharide-inducible nitric oxide synthase (iNOS) activity and reduced prostaglandin E2 production, which were related with its anti-inflammatory and cyclooxygenase inhibition effects, respectively [40, 41]. In addition, its antagonistic impact on CaM was found about 3-fold more effective than CTZ [8]. Interestingly, we could not discover any study that has assessed the effect of ENZ on glycolysis pathway. It is maybe because of the least selectivity of this azole antifungal against CaM-dependent PDE [8]. On the other hand, as a $\mathrm{Ca}^{2+}$ influx blocker, the effectiveness of ENZ on various tumors by different action mechanisms has been demonstrated (Table 2). Zhang et al. stated that MCF-7 and MDA-MB231 breast cancer cell lines lost their viability after treatment with ENZ for $24 \mathrm{~h}$ in a dose dependent manner $(0-15 \mu \mathrm{M})$, the concentration range which was slightly higher in magnitude than those required to kill bone marrow derived murine mast or 32D-Kit leukemia cells [42, 43]. In the same studies, it was also showed that ENZ caused a sharp loss of cell clonogenicity almost above $10 \mu \mathrm{M}$ in parental and doxorubicin-resistant MCF-7 and MDA-MB-231 breast cancers, and 32D-Kit leukemia cells. However, unlike mast, p815 mastocytoma or 32D-Kit leukemia, the so-called breast cancer cell lines did not exhibit typical apoptotic morphology. Importantly, it should be also stated that this imidazole plus epithelial growth factor combination was successfully utilized for the purpose of decontamination of hematopoietic 
progenitor cell preparations from breast cancer cells, in other terms for in vitro purging [42]. A similar ENZ application was shown for in vitro purging of bone marrow from P815 leukemic cells [44]. Ho and his friends showed the molecular mechanisms of ENZ induced antiproliferative effect on human colon cancer cells [45]. According to their results, while lower doses of ENZ $(5-10 \mu \mathrm{M})$ suppressed COLO 205 cell proliferation, higher doses $(>20 \mu \mathrm{M})$ triggered apoptotic cell death characterized by DNA ladder formation, caspase-3 and -9 activation, induction in Bax protein expression, translocation of cytochrome $\mathrm{c}$ and apoptosis inducing factor from mitochondria to cytosol. In an another study, it was found that overnight treatment of the human prostate cancer cell line PC3 with 1-30 $\mu \mathrm{M}$ ENZ resulted in a decrease in cell proliferation by $20-100 \%$ and $5 \mu \mathrm{M}$ of the drug induced both extracellular $\mathrm{Ca}^{2+}$ influx and intracellular $\mathrm{Ca}^{2+}$ release in this cell line [46]. In this point it must be stated that although ENZ generally recognized as an inhibitor of capacitative $\mathrm{Ca}^{2+}$ entry through store-operated calcium channels, it has been found to increase intracellular $\mathrm{Ca}^{2+}$ levels in some other cell lines too [39, 47-53]. Yu et al. showed the modulator function of c-myc and hypoxia-inducible factor 1 transcription factors in regulating ENZ sensitivity of rat fibroblast and human myelomonocytic leukemia cells [54]. While Fang et al. showed ENZ induced caspase-12 and 7 dependent apoptosis in mouse leukemia [55], caspase-3, -9 and Bcl-2 dependent apoptotic death was demonstrated for MCF-7 breast cancer cells [56].

Table 2. Action mode of econazole-induced death on several cell lines and tissues ( ${ }^{a}$ Carried out only on the human colon adenocarcinoma)

\begin{tabular}{ccc}
\hline Mode of Action & Cell/Tissue Type & References \\
\hline
\end{tabular}

Inhibition of the tumor weight and the tumor/body

weight ratio in human colon cancer xenografts

\section{At lower doses (5 - $20 \mu \mathrm{M})$}

Dose-dependently suppression of in vitro cell proliferation but in a less profound manner in healthy ones,

Induction of cell cycle arrest at the G0/G1 phase in a dose-dependent manner ${ }^{\text {a }}$,

Induction in p53, p21/Cip1, p27/Kip1 and cyclin E protein levels in a dose-dependent manner a ,

Decreases in the expression of phospho-CDK2 and phospho- $\mathrm{Rb}$ proteins in a dose-dependent manner ${ }^{\mathrm{a}}$ Suppression of CDK2 and CDK4 kinase activities ${ }^{a}$

\section{At higher doses $(>20 \mu \mathrm{M})$}

human normal colon epithelial cell line, human colon adenocarcinoma cell line, human colon cancer xenografts

Induction of in vitro cell death but in a less profound manner in healthy ones,

Arrestment at the sub-G1 peak phase a,

Downregulation in phospho-CDK2, CDK4, cyclins

A2, D1 and D3 protein levels a,

Apoptosis induction evidenced by DNA ladder

formation ${ }^{\mathrm{a}}$,

Caspase- 3 and -9 activation ${ }^{\text {a }}$

Induction in Bax protein expression ${ }^{a}$,

Translocation of cytochrome $\mathrm{c}$ and apoptosis-

inducing factor ${ }^{\text {a }}$

Dose-dependently induction of intracellular $\mathrm{Ca}^{2+}$ concentration by stimulating $\mathrm{Ca}^{2+}$ influx into cells and $\mathrm{Ca}^{2+}$ release from the endoplasmic reticulum

human prostate adenocarcinoma in vivo

via a phospholipase $\mathrm{C}$ independent mechanism

Induction in intracellular $\mathrm{Ca}^{2+}$ concentration in a dose-dependent manner, cell line 
Apoptosis induction evidenced by

phosphatidylserine externalization in a dose-

dependent manner,

Induction in expression of caspase-12 and caspase-

7 in a dose-dependent manner

Cell resistance in terms of colony-forming ability

in c-myc negative rat fibroblasts,

Reduced level of apoptosis showed by Annexin V-

Cy5 staining in c-myc knock-down leukemia cells

compared with vector control-infected ones,

Impaired $\mathrm{ER} \mathrm{Ca}^{2+}$ release in c-myc-negative rat fibroblasts,

Reduced ROS generation in c-myc-negative rat fibroblasts and c-myc knock-down leukemia cells related with decrease in mitochondrial content, Restoration of the sensitivity with the addition of

human leukemia cell line, rat fibroblast cells (c-myc-negative and -positive)

$\mathrm{H}_{2} \mathrm{O}_{2}$ in terms of apoptosis in c-myc-negative rat fibroblasts and c-myc knock-down leukemia cells, Restoration of mitochondrial content, ROS generation and the sensitivity in terms of apoptosis in c-myc negative rat fibroblasts with HIF-1 $\alpha$ knock-down

Dose-dependently induction of intracellular $\mathrm{Ca}^{2+}$ concentration by stimulating $\mathrm{Ca}^{2+}$ influx into cells and $\mathrm{Ca}^{2+}$ release from the endoplasmic reticulum via phospholipase $\mathrm{A} 2$ and $\mathrm{C}$ and protein kinase $\mathrm{C}$ dependent mechanisms,

Induction of cell death regulated by ERK/MAPK pathway

Reduction in cell viability in a time- and dosedependent manner,

Reduction in cell growth in a dose-dependent

manner,

Decrease in cell number,

Apoptosis induction evidenced by the induction of morphological changes including blebbing of nuclei and formation of granular apoptotic bodies, and the appearance of DNA ladder,

Decrease in mitochondrial membrane potential in a dose-dependent manner,

Decrease in Bcl-2, and increase in caspase- 3 and -9 protein levels

Reduction in cell viability in a dose-dependent manner,

Dose-dependently induction of apoptosis evidenced

by Annexin V-FITC staining, and PARP and

caspase- 3 cleavages,

Decrease in p-AKT and Bcl-2 protein levels, Synergistic and additive killing effects when combined with cisplatin

\subsubsection{Ketoconazole}

Although both CTZ and ENZ have been accepted as antifungal drugs possessing profound anti-proliferative effects on tumorigenic and metastatic cells while having minimal effects on non-tumoral ones [27, 42, 57], there is no any (un)approved application or combination formulation, most probably because of the need of a more complete understanding of their action mechanisms and bioavailability limitations. However, another imidazole KTZ (1-[4-[4[[(2S,4R)-2-(2,4-dichlorophenyl)-2-(imidazol-1-ylmethyl)-1,3-dioxolan-4-yl]methoxy]phenyl 
]piperazin-1-yl]ethanone) has found application in castration-resistant prostate cancer (CRPC) as an off-label and a second-line hormonal treatment, alone or in combination with other compounds and therapies, since the 1980s [58-71]. It should be noted that this is an officially unapproved treatment, generally without survival benefit. CRPC is defined as the lethal phenotype of prostate cancer and it can occur in most of the patients received long-term androgen deprivation therapy (ADT) which is the standard initial management for the disease. KTZ nonspecifically inhibits CYP450 enzymes including 17 $\alpha$-hydroxylase/17, 20 lyase (CYP17A1), the function of which is to catalyze significant reactions in the gonadal and adrenal steroidogenesis pathways [72, 73]. Based on these inhibitions, the drug suppresses both gonadal and adrenal androgen synthesis, while only gonadal androgen synthesis can be suppressed with ADT. Of course, nonspecific action of this antifungal on CYP450 enzyme family has given rise to concerns about its potential toxicity, the most common of which is hepatotoxicity. As a matter of fact, the usage of oral KTZ tablets in their primary target fungal infections has not been allowed due to its side effects in liver [74]. Nevertheless, the efficacy and safety of cancer treatment were enhanced by clinical dose-reduction studies. For example, Harris et al. indicated a regimen of low dose oral KTZ (200 mg 3 times daily) with replacement doses of hydrocortisone which can be well tolerated and has moderate activity in CRPC patients [75]. Again a significant improvement in terms of toxicity was achieved by clinical dose reduction (from 400 to $200 \mathrm{mg}$ orally 3 times daily) not or in combination with steroids again in CRPC patients [76]. In a more recent study conducted with docetaxel pre-treated CRPC patients, low dose oral KTZ (200 mg 3 times daily) plus hydrocortisone regimen was suggested as welltolerated, relatively inexpensive and clinically active treatment alternative [77]. Of course, the number of these examples can be increased. Moreover, similar applications have been suggested and extended for other tumors such as breast and colorectal carcinomas [78, 79]. From this point of view, KTZ yet offers alternative ways for the treatment of advanced cancers with its low-priced, a relatively favorable toxicity profile compared to chemotherapy and efficacy both before and after chemotherapy $[80,81]$ especially when newer and more specific options are not available [71, 82-84].

As can be seen in Table 3, KTZ also has cytotoxic effects on different tumors. In an old study conducted by Naftalovich et al., it was demonstrated that 4-7 $\mu \mathrm{g} / \mathrm{ml} \mathrm{KTZ} \mathrm{caused} \mathrm{to} 50 \%$ inhibition of DNA synthesis in radiation leukemia virus induced T-cell lymphomas, while at least $50 \mu \mathrm{g} / \mathrm{ml}$ of the drug was needed to induce a similar inhibition in bone-marrow and spleen cells prepared from healthy mice [85]. 25-50 $\mu \mathrm{M} \mathrm{KTZ} \mathrm{was} \mathrm{shown} \mathrm{to} \mathrm{have} \mathrm{cytotoxic} \mathrm{and}$ apoptotic effects on both different human cancer and rat liver cells, but in a significantly more sensitive manner when wild-type p53 protein was present [86]. The same group demonstrated that wild type p53 dependency of KTZ- induced cytotoxicities in human colorectal and hepatocellular carcinoma cell lines were more pronounced at lower doses $(2 \mu \mathrm{M})$ of the antifungal [87]. Additionally, it was stated that approximately $40 \mu \mathrm{M}$ KTZ induced p53mediated cell cycle arrest at the G0/G1 phase together with p21/Cip1 induction and decrease in Cdk activities, especially in Cdk4. Lin et al. exerted cytotoxic and apoptotic effects of KTZ above the concentration of $20 \mu \mathrm{M}$ on human osteosarcoma cells [88]. While this observed cell death depended on KTZ-induced JNK phosphorylation, it was independent from the increase in intracellular $\mathrm{Ca}^{2+}$ concentrations. In a current work of Agnihotri et al., it was firstly found by means of drug-screening research that $\mathrm{KTZ}$ and posaconazole, a second-generation triazole agent, displayed the greatest inhibitory effect on glioblastoma both in vitro and in vivo by effecting hexokinase II-related gene expression signature [89]. This finding has special importance in terms of the lack of specific hexokinase II inhibitors, which makes this enzyme unactionable in cancer medicine. Considering the findings that azole antifungal drugs have given rise to mitochondrial loss $[90,91]$, Chen et al. put forward a novel impact of KTZ on mitophagy programme of hepatocellular carcinoma cells [92]. According to the data of the 
researchers, $20 \mu \mathrm{M} \mathrm{KTZ} \mathrm{induced} \mathrm{apoptosis} \mathrm{of} \mathrm{liver} \mathrm{cancer} \mathrm{cells} \mathrm{by} \mathrm{triggering} \mathrm{aberrant}$ mitophagy with the downregulation of cyclooxygenase- 2 . The same researchers also indicated the synergistic action of KTZ with clinically approved multi-kinase inhibitor sorafenib and rightfully suggested the use of KTZ especially in patients having high cyclooxygenase- 2 expression levels.

Some other medically important in vitro effects of KTZ are the induction of the DTDiaphorase (NQO1), modulation of the calcium-activated potassium channels, blockage of the activation of orphan nuclear receptors (NRs), and specific and reversible inhibition of CYP3A4 [79, 93-96]. NQO1 is one of the phase II enzymes that detoxificate xenobiotics. Accordingly, KTZ induction of the enzyme indicates the chemoprotection function of this antifungal. The associations between key aspects of cancer and potassium channel dysregulation are gradually growing, which makes potassium channels a valuable target [97]. On the other hand, when the literature is examined, it can be clearly seen that researchers especially have focused on the inhibition effects of KTZ on NRs and CYP3A4. As is well known, these receptors play role in the regulation of CYP3A4, which accounts for approximately half of the metabolism of most approved drugs [98]. Based on the KTZ induced inhibition of this enzyme and, therefore, the reduction in drug clearance, alternative and effective formulas benefiting from the so-called antifungal have been developed for advanced cancer patients [79, 99-101].

Table 3. Action mode of ketoconazole-induced death on several cell lines and tissues $\left({ }^{a}\right.$ Used to determine cytotoxicity; ${ }^{b}$ Used to determine cytotoxicity and DNA fragmentation; ${ }^{c} O n$ hepatocellular carcinoma with wild $p 53 ;{ }^{d}$ On colon adenocarcinoma with mutant $p 53 ;{ }^{e}$ On hepatocellular carcinomas; ${ }^{f}$ On colon adenocarcinomas; ${ }^{g}$ On colon and liver cancers)

\begin{tabular}{lcc}
\hline \multicolumn{1}{c}{ Mode of Action } & Cell/Tissue Type & References \\
\hline $\begin{array}{l}\text { Cytotoxicity in a dose and time dependent } \\
\text { manner }\end{array}$ & human breast carcinomas, \\
& human pancreatic \\
& adenocarcinomas, human \\
& colon adenocarcinoma, \\
& human prostate carcinoma, \\
& rat pancreatic carcinoma, \\
& murine leukemia \\
\hline
\end{tabular}

Increased sensitivity to the cytotoxicity and apoptosis depend on carrying wild type p53 and being cancerous,

Induction of apoptosis evidenced by the formation of DNA fragment ladder in all cell lines,

Nuclear accumulation of $\mathrm{p} 53$ protein $\mathrm{c}$, Bax protein induction e and bcl-2 protein inhibition $\mathrm{g}$,

Activation of caspase- 3 c,

Poly-(ADP ribose) polymerase and lamin A

normal human breast skin fibroblast cell line a, primary culture of rat liver cells b, human colon adenocarcinomas (with wild or mutant types p53), human hepatocellular carcinomas (with wild type or deleted p53)

degradation $\mathrm{c}$

Increased sensitivity to the cytotoxicity depend on carrying wild type $\mathrm{p} 53$, Increased sensitivity to cell cycle arrest at G0/G1 phase depend on carrying wild type p53 f,

G0/G1 arrest mediated by induction in p21/Cip1, p27/Kip1 and inhibition in cyclin D3 and CDK4 expressions d

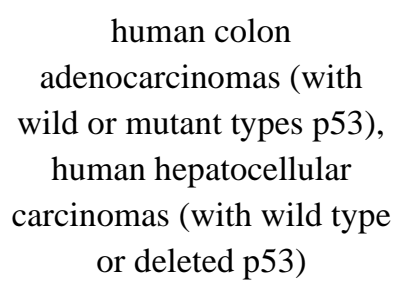




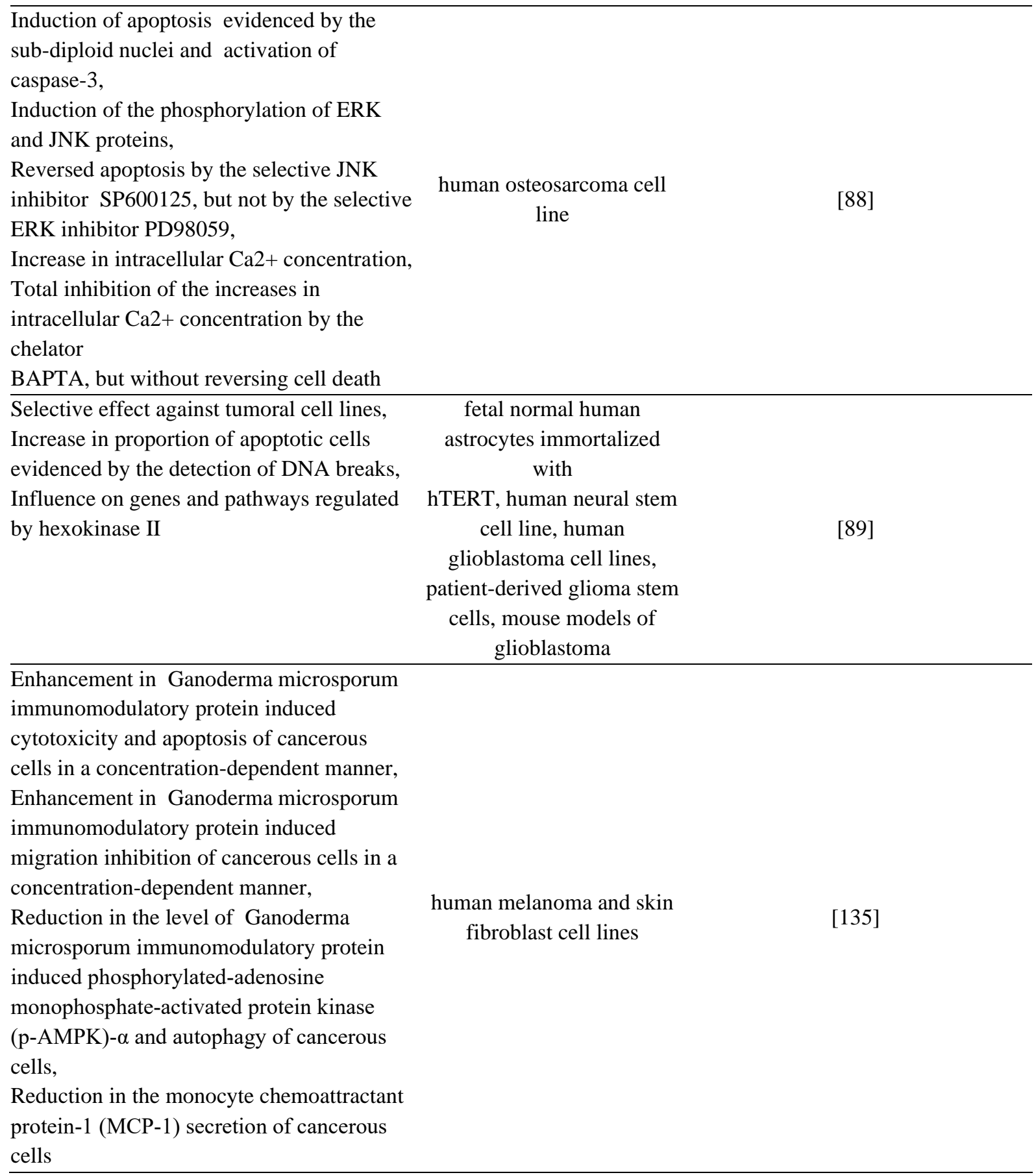

\subsubsection{Other Imidazoles}

Apart from these three drugs, there are some studies on the possible anticancer effects of some other remaining imidazoles including bifonazole (BFZ) and miconazole (MCZ). As in the case of CTZ, BFZ has been known as calmodulin antagonist for more than two decades which can detach glycolytic enzymes from cytoskeleton or mitochondria in murine melanoma cells [23]. In a more recent study, Cheng et al. demonstrated the BFZ-induced intracellular $\mathrm{Ca}^{2+}$ increases in human prostate cancer cells through the induction of phospholipase $\mathrm{C}$ - and protein kinase $\mathrm{C}$-dependent $\mathrm{Ca}^{2+}$ release from the endoplasmic reticulum and $\mathrm{Ca}^{2+}$ influx via non-storeoperated pathways [102]. The researchers also recorded $\mathrm{Ca}^{2+}$-independent apoptotic cell death in these cells. We finally came across the abstract paper of Robey et al. in which synergistic apoptotic effects of romidepsin, a histone deacetylase inhibitor, plus CTZ/BFZ were found on colon, lung, breast and renal cancer cell lines [103]. Surprisingly, no other studies on the effects 
of BFZ or its combination formulations on cancer cells/tissues have been discovered and therefore it is thought that the action mechanism of this drug is still in need of investigation. Nevertheless, it would not be wrong to say that the action mechanism of MCZ on cancer cells is relatively better understood compared to BFZ. Literature review shows that this drug has an impact on human bladder, breast and colorectal cancers, human osteosarcoma cells, human hepatocellular carcinoma, human acute myelogenous leukemia, and mouse skin melanoma cells [104-108]. It is clearly seen that the main focus of these studies was to explore the relationship between MCZ-induced cell-cycle arrest and apoptosis via the determination of the levels of main regulatory proteins involved in the so-called processes. Unfortunately, this antifungal causes cardiotoxicity via generation of superoxide anion, inhibition of APE/Ref- 1 and induction of apoptosis in cardiomyocytes and cardiomyoblast cell line [109, 110], which might make it unnecessary to focus on researches regarding with its anticancer potential.

\subsection{Triazoles}

As stated at the beginning of the paper, triazole antifungal drugs having three nitrogen atoms in their azole rings were developed to fulfill the need of a much broader spectrum of treatment options by comparison with the imidazoles. The first synthetic triazole antifungal to be discovered was fluconazole (FCZ) and it was introduced to the markets in the early 90s [111]. By the way, FCZ is different from other azoles in terms of the presence of two triazole rings making this compound less lipophilic and protein bound [112]. After FCZ, itraconazole (ICZ) is the second member of first generation triazoles. Between these two triazoles, while it has been shown that ICZ is toxic to various cancer types, no study on the subject has been found for FCZ. On the other hand, although it is off topic, it could be useful to say that some Candida cells, a kind of yeast species causing fungemia to which cancer patients are especially susceptible, are resistant to FCZ-induced death and this resistance can be broken by combined application of FCZ with certain phenolic compounds [113-115].

As mentioned above, ICZ has capability to inhibit the proliferation of distinct cell lines established from breast, gastric, glioma, pancreatic, melanoma, esophageal, gastrointestinal, non-small cell lung cancers and acute myeloid leukemia [116-123]. It can be reported that the prominent anticancer mechanism of this triazole is the inhibition of hedgehog pathway having important function in the embryonic development and tissue homeostasis. Moreover, recent findings have put forward that this signaling cascade is related with the neoplastic transformations, malignant tumors and drug resistance of a multitude of cancers [124]. The relationship with drug resistance may be especially remarkable given the findings suggesting that ICZ has a synergistic effect when combined with the known drugs as bevacizumab, doxorubicin and 5-fluorouracil on several cancer cell lines resisting these drugs when they are given alone [117, 121, 123]. In addition, the review paper conducted by Tsubamoto et al. can be browsed for more detailed information for both in vitro and ongoing in vivo trials with ICZ [125].

Approximately a decade later from the first generation triazoles, voriconazole, posaconazole, ravuconazole, albaconazole, isavuconazole and efinaconazole were developed as second-generation triazole antifungals for more efficiency and safety [126]. As with FCZ, there are no detailed researches dealing with the action mechanisms of these triazoles against cancer cells. However, due to the limited treatment strategies available because of the reasons including antifungal resistance, toxicity, drug interactions and expense; clinical studies are being conducted to evaluate the potentials of the so-called antifungals against invasive fungal infections in patients with cancer whose immune systems are severely suppressed [127, 128]. In short, when it comes to cancer, basic focus for triazoles is the modulation of fungal population aiming at increasing morbidity and mortality in cancer patients and ICZ is the only triazole whose effects on cancers have been broadly investigated. 


\section{CONCLUSION}

As a conclusion, it is clear that imidazole antifungals have additional anti-proliferative effects against divergent solid and leukemia tumors. In this sense, CTZ, ENZ and KTZ can be said to be most striking imidazole antifungals with their significant in vitro effects that may be valuable in medicine. Despite above-mentioned remarkable data, to be sure, it would be appropriate to continue investigate the new biological effects of all imidazoles besides CTZ, ENZ and KTZ. Additionally, it should not be forgotten that although KTZ has already found a medical application, the same situation is not valid for other imidazoles for the time being. Accordingly, as with the usage of KTZ in especially prostate cancer, the significance and effectiveness of sequential applications or combined therapies in many diseases including cancer must be taken notice. It can be clearly said that application of dual drugs with known pharmacology and complementary to each other in terms of their targets has always been a valuable option for the scientists in the area due to difficulty of and requiring a long time for new drug developments. Eventually, considering the biochemical effects on cancer cells, the so-called antifungal drugs should be also taken into account in combined therapies, maybe particularly with new generation anticancer drugs that are target specific but against which cancer cells can resist.

\section{Declaration of Conflicting Interests and Ethics}

The authors declare no conflict of interest. This research study complies with research publishing ethics. The scientific and legal responsibility for manuscripts published in IJSM belongs to the author(s).

\section{Orcid}

Berna Kavakcığlu Yardımc1 (D) https://orcid.org/0000-0003-0719-9094

\section{REFERENCES}

[1]. Almutairi, M.S., Manimaran, D., Joe, I.H., Saleh, O.A., Attia, M.I. (2015). Structural properties and biological prediction of (\{[(1E)-3-(1H-Imidazol-1-yl)-1phenylpropylidene]amino\}oxy)(4-methylphenyl) methanone: An in silico approach. Symmetry, 8(1), 1.

[2]. Campoy, S., Adrio, J.L. (2017). Antifungals. Biochem. Pharmacol., 133, 86-96.

[3]. Sheehan, D.J., Hitchcock, C.A., Sibley, C.M. (1999). Current and emerging azole antifungal agents. Clin. Microbiol. Rev., 12(1), 40-79.

[4]. Allen, D., Wilson, D., Drew, R., Perfect, J. (2015). Azole antifungals: 35 years of invasive fungal infection management. Expert Rev. Anti-infect. Ther., 13(6), 787-798.

[5]. Kadavakollu, S., Stailey, C., Kunapareddy, C.S., White, S. (2014). Clotrimazole as a cancer drug: a short review. Med. Chem., 4(11), 722.

[6]. Sequeira, S.O., Laia, C.A.T., Phillips, A.J.L., Cabrita, E.J., Macedo, M.F. (2017). Clotrimazole and calcium hydroxide nanoparticles: A low toxicity antifungal alternative for paper conservation. J. Cult. Herit., 24, 45-52.

[7]. Spiekermann, P.H., Young, M.D. (1976). Clinical evaluation of clotrimazole: a broadspectrum antifungal agent. Arch. Dermatol., 112(3), 350-352.

[8]. Hegemann, L., Toso, S.M., Lahijani, K.L., Webster, G.F., Uitto, J. (1993). Direct interaction of antifungal azole-derivatives with calmodulin: a possible mechanism for their therapeutic activity. J. Investig. Dermatol., 100(3), 343-346.

[9]. Stevens, F.C. (1983) Calmodulin: an introduction. Biochem. Cell Biol., 61(8), 906-910.

[10]. Hidaka, H., Hartshorne, D.J. (1985). Calmodulin Antagonists and Cellular Physiology, Academic: New York.

[11]. Arnold, H., Pette, D. (1968). Binding of glycolytic enzymes to structure proteins of the muscle. Eur. J. Biochem., 6(2), 163-171. 
[12]. Gots, R.E., Bessman, S.P. (1974). The functional compartmentation of mitochondrial hexokinase. Arch. Biochem. Biophys., 163(1), 7-14.

[13]. Gots, R.E., Gorin, F.A., Bessman, S.P. (1972). Kinetic enhancement of bound hexokinase activity by mitochondrial respiration. Biochem. Biophys. Res. Commun., 49(5), 12491255.

[14]. Viitanen, P.V., Geiger, P.J., Erickson-Viitanen, S., Bessman, S.P. (1984). Evidence for functional hexokinase compartmentation in rat skeletal muscle mitochondria. J. Biol. Chem., 259(15), 9679-9686.

[15]. Eigenbrodt, E., Fister, P., Reinacher, M. New Perspectives on Carbohydrate Metabolism in Tumor Cells In: Regulation of Carbohydrate Metabolism, Rivka Beitner, Ed. CRC Press: Boca Raton, 1985, Vol. 2, pp. 141-79.

[16]. Kottke, M., Adam, V., Riesinger, I., Bremm, G., Bosch, W., Brdiczka, D., Sandri, G., Panfili, E. (1988). Mitochondrial boundary membrane contact sites in brain: points of hexokinase and creatine kinase location, and control of $\mathrm{Ca} 2+$ transport. Biochim. Biophys. Acta-Bioenerg., 935(1), 87-102.

[17]. Feichter, A., Gmunder, FK. Metabolic control of glucose degradation in yeast and tumor cells. (1989). Adv. Biochem. Eng. Biotechnol., 39, 1-28.

[18]. Beckner, M.E., Stracke, M.L., Liotta, L.A., Schiffmann, E. (1990). Glycolysis as primary energy source in tumor cell chemotaxis. J. Natl. Cancer. I., 82(23), 1836-1840.

[19]. Greiner, E.F., Guppy, M., Brand, K. (1994). Glucose is essential for proliferation and the glycolytic enzyme induction that provokes a transition to glycolytic energy production. $J$. Biol. Chem., 269(50), 31484-31490.

[20]. Benzaquen, L.R., Brugnara, C., Byers, H.R., Gattoni-Celli, S., Halperin, J.A. (1995). Clotrimazole inhibits cell proliferation in vitro and in vivo. Nat. Med., 1(6), 534.

[21]. Glass-Marmor, L., Morgenstern, H., Beitner, R. (1996). Calmodulin antagonists decrease glucose 1, 6-bisphosphate, fructose 1, 6-bisphosphate, ATP and viability of melanoma cells. Eur. J. Pharmacol., 313(3), 265-271.

[22]. Glass-Marmor, L., Beitner, R. (1997). Detachment of glycolytic enzymes from cytoskeleton of melanoma cells induced by calmodulin antagonists. Eur. J. Pharmacol., 328(2-3), 241-248.

[23]. Penso, J., Beitner, R. (1998). Clotrimazole and bifonazole detach hexokinase from mitochondria of melanoma cells. Eur. J. Pharmacol., 342(1), 113-117.

[24]. Penso, J., Beitner, R. (2002). Clotrimazole decreases glycolysis and the viability of lung carcinoma and colon adenocarcinoma cells. Eur. J. Pharmacol., 451(3), 227-235.

[25]. Meira, D.D., Marinho-Carvalho, M.M., Teixeira, C.A., Veiga, V.F., Da Poian, A.T., Holandino, C., S. de Freitas, M., Sola-Penna, M. (2005). Clotrimazole decreases human breast cancer cells viability through alterations in cytoskeleton-associated glycolytic enzymes. Mol. Genet. Metab., 84(4), 354-362.

[26]. Liu, H., Li, Y., Raisch, K.P. (2010). Clotrimazole induces a late G1 cell cycle arrest and sensitizes glioblastoma cells to radiation in vitro. Anti-Cancer Drugs, 21 (9), 841.

[27]. Furtado, C.M., Marcondes, M.C., Sola-Penna, M., De Souza, M.L., Zancan, P. (2012). Clotrimazole preferentially inhibits human breast cancer cell proliferation, viability and glycolysis. PloS one, 7(2), e30462.

[28]. McDonald, A.J., Curt, K.M., Patel, R.P., Kozlowski, H., Sackett, D.L., Robey, R.W., Gottesman, M.M, Bates, S.E. (2019). Targeting mitochondrial hexokinases increases efficacy of histone deacetylase inhibitors in solid tumor models. Exp. Cell Res., 375(2), 106-112.

[29]. Khalid, M.H., Shibata, S., Hiura, T. (1999). Effects of clotrimazole on the growth, morphological characteristics, and cisplatin sensitivity of human glioblastoma cells in vitro. J. Neurosurg., 90(5), 918-927. 
[30]. Ito, C., Tecchio, C., Coustan-Smith, E., Suzuki, T., Behm, F.G., Raimondi, S.C., Pui, C.H, Campana, D. (2002). The antifungal antibiotic clotrimazole alters calcium homeostasis of leukemic lymphoblasts and induces apoptosis. Leukemia, 16(7), 1344.

[31]. Wang, J., Jia, L., Kuang, Z., Wu, T., Hong, Y., Chen, X., Leung, W.K., Xia, J., Cheng, B. (2014). The in vitro and in vivo antitumor effects of clotrimazole on oral squamous cell carcinoma. PloS one, 9(6), e98885.

[32]. Sharma, A., Mehta, V., Parashar, A., Malairaman, U. (2017). Combinational effect of Paclitaxel and Clotrimazole on human breast cancer: Proof for synergistic interaction. Synergy, 5, 13-20.

[33]. Kavakçığlu, B., Tarhan, L. (2018). Yeast caspase-dependent apoptosis in Saccharomyces cerevisiae BY4742 induced by antifungal and potential antitumor agent clotrimazole. Arch. Microbiol., 200(1), 97-106.

[34]. Robles-Escajeda, E., Martínez, A., Varela-Ramirez, A., Sánchez-Delgado, R.A., Aguilera, R.J. (2013). Analysis of the cytotoxic effects of ruthenium-ketoconazole and ruthenium-clotrimazole complexes on cancer cells. Cell Biol. Toxicol., 29(6), 431-443.

[35]. Motawi, T.M., Sadik, N.A., Fahim, S.A., Shouman, S.A. (2015). Combination of imatinib and clotrimazole enhances cell growth inhibition in T47D breast cancer cells. Chem. Biol. Interact., 233, 147-156.

[36]. Dellenbach, P., Thomas, J.L., Guerin, V., Ochsenbein, E., Contet-Audonneau, N. (2000). Topical treatment of vaginal candidosis with sertaconazole and econazole sustainedrelease suppositories. Int. J. Gynaecol. Obstet., 71, 47-52.

[37]. Bossche, H.V., Engelen, M., Rochette, F. (2003). Antifungal agents of use in animal health-chemical, biochemical and pharmacological aspects. J. Vet. Pharmacol. Ther., 26(1), 5-29.

[38]. Prajna, N.V., John, R.K., Nirmalan, P.K., Lalitha, P., Srinivasan, M. (2003). A randomised clinical trial comparing $2 \%$ econazole and 5\% natamycin for the treatment of fungal keratitis. Br. J. Ophthalmol., 87(10), 1235-1237.

[39]. Kuo, D.H., Liu, L.M., Chen, H.W., Chen, F.A., Jan, C.R. (2010). Econazole-induced Ca2+ fluxes and apoptosis in human oral cancer cells. Drug Dev. Res., 71(4), 240-248.

[40]. Jiang, Y.Y., Zhang, B., Chen, X.S., Long, K. (1991). Effects of econazole and clotrimazole on TXB2 and PGE2 production in calcimycin-stimulated neutrophils and arachidonic acid-stimulated platelets. Acta Pharmacol. Sin., 12(3), 276-280.

[41]. Bogle, R.G., Vallance, P. (1996). Functional effects of econazole on inducible nitric oxide synthase: production of a calmodulin-dependent enzyme. Br. J. Pharmacol., 117(6), 1053-1058.

[42]. Zhang, Y., Crump, M., Berger, S.A. (2002). Purging of contaminating breast cancer cells from hematopoietic progenitor cell preparations using activation enhanced cell death. Breast Cancer Res. Treat., 72(3), 265-278.

[43]. Gommerman, J.L., Berger, S.A. (1998). Protection from apoptosis by steel factor but not interleukin-3 is reversed through blockade of calcium influx. Blood, 91(6), 1891-1900.

[44]. Soboloff, J., Zhang, Y., Minden, M., Berger, S.A. (2002). Sensitivity of myeloid leukemia cells to calcium influx blockade: application to bone marrow purging. Exp. Hematol., 30(10), 1219-1226.

[45]. Ho, Y.S., Wu, C.H., Chou, H.M., Wang, Y.J., Tseng, H., Chen, C.H., Chen, L.C., Lee, C.H., Lin, S. Y. (2005). Molecular mechanisms of econazole-induced toxicity on human colon cancer cells: G0/G1 cell cycle arrest and caspase 8-independent apoptotic signaling pathways. Food Chem. Toxicol., 43(10), 1483-1495.

[46]. Huang, J.K., Liu, C.S., Chou, C.T., Liu, S.I., Hsu, S.S., Chang, H.T., Hsieh, C.H., Chang, C.H., Chen, W.C., Jan, C.R. (2005). Effects of econazole on Ca2+ levels in and the growth of human prostate cancer PC3 cells. Clin. Exp. Pharmacol. Physiol., 32(9), 735-741. 
[47]. Mason, M.J., Mayer, B., Hymel, L.J. (1993). Inhibition of Ca2+ transport pathways in thymic lymphocytes by econazole, miconazole, and SKF 96365. Am. J. Physiol. Cell Physiol., 264(3), C654-C662.

[48]. Hughes, A.D., Schachter, M. (1994). Multiple pathways for entry of calcium and other divalent cations in a vasculr smooth muscle cell line (A7r5). Cell Calcium, 15(4), 317330 .

[49]. Hornstein, E.H., Vassilopoulos, D., Thomas, D.E., Friedman, F.K., Tsokos, G.C. (1996). Modulation of human T-lymphocyte plasma membrane $\mathrm{Ca}+2$ permeability by imidazole antimycotics. Immunopharmacol. Immunotoxicol., 18(2), 237-245.

[50]. Gamberucci, A., Fulceri, R., Bygrave, F.L., Benedetti, A. (1997). Unsaturated fatty acids mobilize intracellular calcium independent of IP3 generation and via insertion at the plasma membrane. Biochem. Biophys. Res. Commun., 241(2), 312-316.

[51]. Jan, C.R., Ho, C.M., Wu, S.N., Huang, J.K., Tseng, C.J. (1998). Mechanism of lanthanum inhibition of extracellular ATP-evoked calcium mobilization in MDCK cells. Life Sci., 62(6), 533-540.

[52]. Jan, C.R., Ho, C.M., Wu, S.N., Tseng, C. J. (1999). Multiple effects of econazole on calcium signaling: depletion of thapsigargin-sensitive calcium store, activation of extracellular calcium influx, and inhibition of capacitative calcium entry. Biochim. Biophys. Acta-Mol. Cell Res., 1448(3), 533-542.

[53]. Chang, H.T., Liu, C.S., Chou, C.T., Hsieh, C.H., Chang, C.H., Chen, W.C., Liu, S.I., Hsu, S.S., Chen, J.S., Jiann, B.P., Huang, J.K., Jan, C.R. (2005). Econazole induces increases in free intracellular $\mathrm{Ca} 2+$ concentrations in human osteosarcoma cells. Hum. Exp. Toxicol., 24(9), 453-458.

[54]. Yu, Y., Niapour, M., Zhang, Y., Berger, S.A. (2008). Mitochondrial regulation by c-Myc and hypoxia-inducible factor-1 $\alpha$ controls sensitivity to econazole. Mol. Cancer Ther., 7(3), 483-491.

[55]. Fang, L.I.U., Ping, Z.O.U., Zhang, M., Yaohui, W.U., Juan, X. (2005). Experimental study on apoptosis in leukemia cells induced by econazole. Chin. Ger. J. Clin. Oncol., 4(2), 102-104.

[56]. Sun, J., Yu, C.H., Zhao, X.L., Wang, Y., Jiang, S.G., Gong, X.F. (2014). Econazole nitrate induces apoptosis in MCF-7 cells via mitochondrial and caspase pathways. Iran J. Pharm. Res., 13(4), 1327.

[57]. Coelho, R.G., de Castro Calaça, I., de Moura Celestrini, D., Correia, A.H., Costa, M.A.S.M., Sola-Penna, M. (2011). Clotrimazole disrupts glycolysis in human breast cancer without affecting non-tumoral tissues. Mol. Genet. Metab., 103(4), 394-398.

[58]. Trachtenberg, J., Pont, A. (1984). Ketoconazole therapy for advanced prostate cancer. Lancet, 324(8400), 433-435.

[59]. Trachtenberg, J., Halpern, N., Pont, A. (1983). Ketoconazole: a novel and rapid treatment for advanced prostatic cancer. J. Urol., 130(1), 152-153.

[60]. Eichenberger, T., Trachtenberg, J. (1989). Effects of high-dose ketoconazole on patients who have androgen-independent prostatic cancer. Can. J. Surg., 32(5), 349-352.

[61]. Eichenberger, T., Trachtenberg, J., Toor, P., Keating, A. (1989). Ketoconazole: a possible direct cytotoxic effect on prostate carcinoma cells. J. Urol., 141(1), 190-191.

[62]. Pont, A. (1987). Long-term experience with high dose ketoconazole therapy in patients with stage D2 prostatic carcinoma. J. Urol., 137(5), 902-904.

[63]. Witjes, F. J., Debruyne, F.M., Del Moral, P.F., Geboers, A.D.H., Group, D.S.E.U.C. (1989). Ketoconazole high dose in management of hormonally pretreated patients with progressive metastatic prostate cancer. Urology, 33(5), 411-415.

[64]. Millikan, R., Baez, L., Banerjee, T., Wade, J., Edwards, K., Winn, R., Smith, T.L., Logothetis, C. (2001). Randomized phase 2 trial of ketoconazole and 
ketoconazole/doxorubicin in androgen independent prostate cancer. Urol. Oncol., 6, 111115.

[65]. Small, E.J., Halabi, S., Dawson, N.A., Stadler, W.M., Rini, B.I., Picus, J., Gable, P., Torti, F.M., Kaplan, E., Vogelzang, N.J. (2004). Antiandrogen withdrawal alone or in combination with ketoconazole in androgen-independent prostate cancer patients: a phase III trial (CALGB 9583). J. Clin. Oncol, 22(6), 1025-1033.

[66]. Figg, W.D., Liu, Y., Arlen, P., Gulley, J., Steinberg, S.M., Liewehr, D.J., Cox, M.C, Zhai, S., Cremers, S., Parr, A., Yang, X., Chen, C.C., Jones, E., Dahut, W.L. (2005). A randomized, phase II trial of ketoconazole plus alendronate versus ketoconazole alone in patients with androgen independent prostate cancer and bone metastases. J. Urol., 173(3), 790-796.

[67]. Eklund, J., Kozloff, M., Vlamakis, J., Starr, A., Mariott, M., Gallot, L., Jovanovic, B., Schilder, L., Robin, E., Pins, M., Bergan, R.C. (2006). Phase II study of mitoxantrone and ketoconazole for hormone-refractory prostate cancer. Cancer, 106(11), 2459-2465.

[68]. Ryan, C.J., Halabi, S., Ou, S.S., Vogelzang, N.J., Kantoff, P., Small, E.J. (2007). Adrenal androgen levels as predictors of outcome in prostate cancer patients treated with ketoconazole plus antiandrogen withdrawal: results from a cancer and leukemia group B study. Clin. Cancer Res., 13(7), 2030-2037.

[69]. Peer, A., Neumann, A., Sella, A., Rosenbaum, E., Neiman, V., Gottfried, M., Kovel, S., Sarid, D., Gez, E., Mermershtain, W., Rouvinov, K., Carducci, M.A., Eisenberg, M.A., Sinibaldi, V.J., Berger, R., Keizman, D. (2017). Comparison of abiraterone acetate (Abi) versus ketoconazole (Keto) in chemotherapy-naive patients (CN-pts) with metastatic castration resistant prostate cancer (mCRPC). J. Clin. Oncol., 34, 3742-3748.

[70]. Barata, P.C., Cooney, M., Mendiratta, P., Tyler, A., Dreicer, R., Garcia, J.A. (2018). Ketoconazole plus Lenalidomide in patients with Castration-Resistant Prostate Cancer (CRPC): results of an open-label phase II study. Invest. New Drug., 36(6), 1085-1092.

[71]. Patel, V., Liaw, B., Oh, W. (2018). The role of ketoconazole in current prostate cancer care. Nature Rev. Urol., 15, 643-651.

[72]. Fernández-Cancio, M., Camats, N., Flück, C., Zalewski, A., Dick, B., Frey, B., Monne, R., Toran, N., Audi, L., Pandey, A. (2018). Mechanism of the dual activities of human CYP17A1 and binding to anti-prostate cancer drug abiraterone revealed by a novel V366M mutation causing 17, 20 lyase deficiency. Pharmaceuticals, 11(2), 37.

[73]. Monticone, S., Rainey, W.E., Bollag, W.B., Isales, C.M. Regulation of Aldosterone Production In: Textbook of Nephro-Endocrinology, Ajay K. Singh, Gordon H. Williams, Ed. Academic Press, 2018, 2, pp. 429-449.

[74]. U.S. Food and Drug Administration. FDA Drug Safety Communication: FDA limits usage of Nizoral (ketoconazole) oral tablets due to potentially fatal liver injury and risk of drug interactions and adrenal gland problems. http://www.fda.gov/Drugs/DrugSafety/ucm362 415.htm (Accessed March 3, 2015).

[75]. Harris, K.A., Weinberg, V., Bok, R.A., Kakefuda, M., Small, E.J. (2002). Low dose ketoconazole with replacement doses of hydrocortisone in patients with progressive androgen independent prostate cancer. J. Urol., 168(2), 542-545.

[76]. Nakabayashi, M., Xie, W., Regan, M.M., Jackman, D.M., Kantoff, P.W., Oh, W.K. (2006). Response to low-dose ketoconazole and subsequent dose escalation to high-dose ketoconazole in patients with androgen-independent prostate cancer. Cancer, 107(5), 975981.

[77]. Lo, E.N., Beckett, L.A., Pan, C.X., Robles, D., Suga, J.M., Sands, J.M., Lara Jr, P.N. (2015). Prospective evaluation of low-dose ketoconazole plus hydrocortisone in docetaxel pre-treated castration-resistant prostate cancer patients. Prostate Cancer P. D., 18(2), 144. 
[78]. Martinez, C., Garcia-Martin, E., Pizarro, R.M., Garcia-Gamito, F.J., Agúndez, J.A.G. (2002). Expression of paclitaxel-inactivating CYP3A activity in human colorectal cancer: implications for drug therapy. Br. J. Cancer, 87(6), 681.

[79]. Lim, Y.W., Goh, B.C., Wang, L.Z., Tan, S.H., Chuah, B.Y.S., Lim, S.E., Lau, P., Buhari, S.A, Chan, C.W., Sukri, N.B., Cordero, M.T., Soo, R., Lee, S.C. (2010). Pharmacokinetics and pharmacodynamics of docetaxel with or without ketoconazole modulation in chemonaive breast cancer patients. Ann. Oncol., 21(11), 2175-2182.

[80]. Blagosklonny, M.V., Dixon, S.C., Figg, W.D. (2000). Efficacy of microtubule-active drugs followed by ketoconazole in human metastatic prostate cancer cell lines. J. Urol., 163(3), 1022-1026.

[81]. Nakabayashi, M., Oh, W.K., Jacobus, S., Regan, M.M., Taplin, M.E., Kantoff, P.W., Rosenberg, J.E. (2010). Activity of ketoconazole after taxane-based chemotherapy in castration-resistant prostate cancer. BJU Int., 105(10), 1392-1396.

[82]. Beer, T.M, Armstrong, A.J., Rathkopf, D.E., Loriot, Y., Sternberg, C.N., Higano, C.S., Iversen, P., Bhattacharya, S., Carles, J., Chowdhury, S., Davis, I.D., de Bono, J.S., Evans, C.P., Fizazi, K., Joshua, A.M., Kim, C.S., Kimura, G., Mainwaring, P., Mansbach, H., Miller, K., Noonberg, S.B., Perabo, F., Phung, D., Saad, F., Scher, H.I., Taplin, M.E., Venner, P.M., Tombal, B. (2014). Enzalutamide in metastatic prostate cancer before chemotherapy. N. Engl. J. Med., 371(5), 424-433.

[83]. Fizazi, K., Tran, N., Fein, L., Matsubara, N., Rodriguez-Antolin, A., Alekseev, B.Y., Özgüroğlu, M., Ye, D., Feyerabend, S., Protheroe, A., De Porre, P., Kheoh, T., Park, Y.C., Todd, M.B., Chi, K.N. (2017). Abiraterone plus prednisone in metastatic, castrationsensitive prostate cancer. N. Engl. J. Med., 377(4), 352-360.

[84]. Smith, M.R., Saad, F., Chowdhury, S., Oudard, S., Hadaschik, B.A., Graff, J.N., Olmos, D., Mainwaring, P.N., Lee, J.Y., Uemura, H., Lopez-Gitlitz, A., Trudel, G.C., Espina, B.M., Shu, Y., Park, Y.C., Rackoff, W.R., Yu, M.K., Small, E.J. (2018). Apalutamide treatment and metastasis-free survival in prostate cancer. N. Engl. J. Med., 378(15), 14081418.

[85]. Naftalovich, S., Yefenof, E., Eilam, Y. (1991). Antitumor effects of ketoconazole and trifluoperazine in murine T-cell lymphomas. Cancer Chemother. Pharmacol., 28(5), 384390.

[86]. Ho, Y.S., Tsai, P.W., Yu, C.F., Liu, H.L., Chen, R.J., Lin, J.K. (1998). Ketoconazoleinduced apoptosis through P53-dependent pathway in human colorectal and hepatocellular carcinoma cell lines. Toxicol. Appl. Pharmacol., 153(1), 39-47.

[87]. Chen, R.J., Lee, W.S., Liang, Y.C., Lin, J.K., Wang, Y.J., Lin, C.H., Hsieh, J.Y., Chaing, C.C., Ho, Y.S. (2000). Ketoconazole induces G0/G1 arrest in human colorectal and hepatocellular carcinoma cell lines. Toxicol. Appl. Pharmacol., 169(2), 132-141.

[88]. Lin, K.L., Huang, C.C., Cheng, J.S., Tsai, J.Y., Lu, Y.C., Chang, H.T., Jan, C.R. (2009). Ketoconazole-induced JNK phosphorylation and subsequent cell death via apoptosis in human osteosarcoma cells. Toxicol. In Vitro, 23(7), 1268-1276.

[89]. Agnihotri, S., Mansouri, S., Burrell, K., Li, M., Mamatjan, Y., Liu, J., Nejad, R., Kumar, S., Jalali, S., Singh, S.K., Vartanian, A., Chen, E.X., Karimi, S., Singh, O., Bunda, S., Mansouri, A., Aldape, K.D., Zadeh, G. (2019). Ketoconazole and posaconazole selectively target HK2-expressing glioblastoma cells. Clin. Cancer. Res., 25(2), 844-855.

[90]. Rodriguez, R.J., Acosta Jr, D. (1996). Inhibition of mitochondrial function in isolated rat liver mitochondria by azole antifungals. J. Biochem. Toxicol., 11(3), 127-131.

[91]. Hynes, J., Nadanaciva, S., Swiss, R., Carey, C., Kirwan, S., Will, Y. (2013). A highthroughput dual parameter assay for assessing drug-induced mitochondrial dysfunction provides additional predictivity over two established mitochondrial toxicity assays. Toxicol. In Vitro, 27(2), 560-569. 
[92]. Chen, Y., Chen, H.N., Wang, K., Zhang, L., Huang, Z., Liu, J., Zhang, Z., Luo, M., Lei, Y., Peng, Y., Zhou, Z.G., Wei, Y., Huang, C. (2019). Ketoconazole exacerbates mitophagy to induce apoptosis by downregulating cyclooxygenase-2 in hepatocellular carcinoma. J. Hepatol., 70(1), 66-77.

[93]. Power, E.C., Ganellin, C.R., Benton, D.C. (2006). Partial structures of ketoconazole as modulators of the large conductance calcium-activated potassium channel (BKCa). Bioorg. Med. Chem., 16(4), 887-890.

[94]. Huang, H., Wang, H., Sinz, M., Zoeckler, M., Staudinger, J., Redinbo, M.R., Teotico, D.G., Locker, J., Kalpana, G.V., Mani, S. (2007). Inhibition of drug metabolism by blocking the activation of nuclear receptors by ketoconazole. Oncogene, 26(2), 258.

[95]. Korashy, H.M., Brocks, D.R., El-Kadi, A.O. (2007). Induction of the NAD (P) H: quinone oxidoreductase 1 by ketoconazole and itraconazole: a mechanism of cancer chemoprotection. Cancer Lett., 258(1), 135-143.

[96]. Pedarzani, P., Stocker, M. (2008). Molecular and cellular basis of small-and intermediateconductance, calcium-activated potassium channel function in the brain. Cell. Mol. Life Sci, 65(20), 3196-3217.

[97]. Huang, X., Jan, L.Y. (2014). Targeting potassium channels in cancer. J. Cell Biol., 206(2), 151-162.

[98]. Zanger, U.M., Schwab, M. (2013). Cytochrome P450 enzymes in drug metabolism: regulation of gene expression, enzyme activities, and impact of genetic variation. Pharmacol. Therapeut., 138(1), 103-141.

[99]. Venkatakrishnan, K., Rader, M., Ramanathan, R.K., Ramalingam, S., Chen, E., Riordan, W., Trepicchio, W., Cooper, M., Karol, M., Moltke, L., Neuwirth, R., Egorin, M., Chatta, G. (2009). Effect of the CYP3A inhibitor ketoconazole on the pharmacokinetics and pharmacodynamics of bortezomib in patients with advanced solid tumors: A prospective, multicenter, open-label, randomized, two-way crossover drug-drug interaction study. Clin. Ther., 31, 2444-2458.

[100]. Kast, R.E., Boockvar, J.A., Brüning, A., Cappello, F., Chang, W.W., Cvek, B., Ping Dou, Q., Duenas-Gonzalez, A., Efferth, T., Focosi, D., Ghaffari, S.H., Karpel-Massler, G., Ketola, K., Khoshnevisan, A., Keizman, D., Magné, N., Marosi, C., McDonald, K., Muñoz, M., Paranjpe, A., Pourgholami, M.H., Sardi, L., Sella, A., Srivenugopal, K.S., Tuccori, M., Wang, W., Wirtz, C.R., Halatsch, M.E. (2013). A conceptually new treatment approach for relapsed glioblastoma: coordinated undermining of survival paths with nine repurposed drugs (CUSP9) by the International Initiative for Accelerated Improvement of Glioblastoma Care. Oncotarget, 4(4), 502.

[101]. Agarwal, S.K., Salem, A.H., Danilov, A.V., Hu, B., Puvvada, S., Gutierrez, M., Chien, D., Lewis, L.D., Wong, S.L. (2017). Effect of ketoconazole, a strong CYP3A inhibitor, on the pharmacokinetics of venetoclax, a BCL-2 inhibitor, in patients with non-Hodgkin lymphoma. Br. J. Clin. Pharmacol., 83(4), 846-854.

[102]. Cheng, J.S., Chou, C.T., Liang, W.Z., Kuo, C.C., Shieh, P., Kuo, D.H., Jan, C.R. (2014). The mechanism of bifonazole-induced $[\mathrm{Ca} 2+] \mathrm{i}$ rises and non-Ca2+-triggered cell death in PC3 human prostate cancer cells. J. Recept. Sig. Transd., 34(6), 493-499.

[103]. Robey, R.W., McDonald, A.J., Kozlowski, H., Gottesman, M.M., Bates, S.E. ShortTerm Romidepsin Treatment Combined with Clotrimazole or Bifonazole Leads to Decreased Mitochondrial Hexokinase 2 and Apoptosis in Cancer Cells In: Proceedings of the American Association for Cancer Research Annual Meeting, Washington, DC., Philadelphia, April 1-5, 2017, doi:10.1158/1538-7445.AM2017-4040.

[104]. Bruserud, O. (2001). Effects of azoles on human acute myelogenous leukemia blasts and $\mathrm{T}$ lymphocytes derived from acute leukemia patients with chemotherapy-induced cytopenia. Int. Immunopharmacol., 1(12), 2183-2195. 
[105]. Yuan, S.Y., Shiau, M.Y., Ou, Y.C., Huang, Y.C., Chen, C.C., Cheng, C.L., Chiu, K.Y., Wang, S.S., Tsai, K.J. (2017). Miconazole induces apoptosis via the death receptor 5dependent and mitochondrial-mediated pathways in human bladder cancer cells. Oncol. Rep., 37(6), 3606-3616.

[106]. Shahbazfar, A.A., Zare, P., Ranjbaran, M., Tayefi-Nasrabadi, H., Fakhri, O., Farshi, Y., Shadi, S., Khoshkerdar, A. (2014). A survey on anticancer effects of artemisinin, iron, miconazole, and butyric acid on 5637 (bladder cancer) and 4T1 (Breast cancer) cell lines. J. Cancer Res. Ther., 10(4), 1057.

[107]. Wu, C.H., Jeng, J.H., Wang, Y.J., Tseng, C.J., Liang, Y.C., Chen, C.H., Lee, H.M., Lin, J.K., Lin, C.H., Lin, S.Y., Li, C.P., Ho, Y.S. (2002). Antitumor effects of miconazole on human colon carcinoma xenografts in nude mice through induction of apoptosis and G0/G1 cell cycle arrest. Toxicol. Appl. Pharm., 180(1), 22-35.

[108]. Mun, Y.J., Lee, S.W., Jeong, H.W., Lee, K.G., Kim, J.H., Woo, W.H. (2004). Inhibitory effect of miconazole on melanogenesis. Biol. Pharm. Bull., 27(6), 806-809.

[109]. Lee, K.P., Kim, J.E., Park, W.H. (2015). Cytoprotective effect of rhamnetin on miconazole-induced H9c2 cell damage. Nutr. Res. Pract., 9(6), 586-591.

[110]. Won, K.J., Lin, H.Y., Jung, S., Cho, S.M., Shin, H.C., Bae, Y.M., Lee, S.H., Kim, H.J., Jeon, B.H., Kim, B. (2012). Antifungal miconazole induces cardiotoxicity via inhibition of APE/Ref-1-related pathway in rat neonatal cardiomyocytes. Toxicol. Sci., 126(2), 298305.

[111]. Ashbee, H.R., Gilleece, M.H. (2014). Pharmacogenomics of Antifungal Agents In: Handbook of Pharmacogenomics and Stratified Medicine, Sandosh Padmanabhan, Ed. Academic Press, pp. 879-896.

[112]. Dash, A.K., \& Elmquist, W.F. (2001). Fluconazole In: Profiles of Drug Substances, Excipients and Related Methodology, HG Brittain, Academic Press: San Diego, 27, 67113.

[113]. Le, A., Farmakiotis, D., Tarrand, J.J., Kontoyiannis, D.P. (2017). Initial treatment of cancer patients with fluconazole-susceptible dose-dependent Candida glabrata fungemia: better outcome with an echinocandin or polyene compared to an azole? Antimicrob. Agents Chemother., 61(8), e00631-17.

[114]. da Silva, C.R., de Andrade Neto, J.B., de Sousa Campos, R., Figueiredo, N.S., Sampaio, L.S., Magalhães, H.I.F., Cavalcanti, B.C., Gaspar, D.M., de Andrade, G.M., Lima, I.S.P., de Barros Viana, G.S., de Moraes, M.O., Lobo, M.D.P., Grangeiro, T.B., Júnior, H.V.N. (2014). Synergistic effect of the flavonoid catechin, quercetin, or epigallocatechin gallate with fluconazole induces apoptosis in Candida tropicalis resistant to fluconazole. Antimicrob. Agents Chemother., 58(3), 1468-1478.

[115]. Singh, B.N., Upreti, D.K., Singh, B.R., Pandey, G., Verma, S., Roy, S., Naqvi, A.H., Rawat, A.K.S. (2015). Quercetin sensitizes fluconazole-resistant Candida albicans to induce apoptotic cell death by modulating quorum sensing. Antimicrob. Agents Chemother., 59(4), 2153-2168.

[116]. Wang, X., Wei, S., Zhao, Y., Shi, C., Liu, P., Zhang, C., Lei, Y., Zhang, B., Bai, B., Huang, Y., Zhang, H. (2017). Anti-proliferation of breast cancer cells with itraconazole: Hedgehog pathway inhibition induces apoptosis and autophagic cell death. Cancer Lett., $385,128-136$.

[117]. Hu, Q., Hou, Y.C., Huang, J., Fang, J.Y., Xiong, H. (2017). Itraconazole induces apoptosis and cell cycle arrest via inhibiting Hedgehog signaling in gastric cancer cells. J. Exp. Clin. Canc. Res., 36(1), 50.

[118]. Liu, R., Li, J., Zhang, T., Zou, L., Chen, Y., Wang, K., Lei, Y., Yuan, K., Li, Y., Lan, J., Cheng, L., Xie, N., Xiang, R., Nice, E.C., Huang, C., Wei, Y. (2014). Itraconazole 
suppresses the growth of glioblastoma through induction of autophagy: involvement of abnormal cholesterol trafficking. Autophagy, 10(7), 1241-1255.

[119]. Chen, M.B., Liu, Y.Y., Xing, Z.Y., Zhang, Z.Q., Jiang, Q., Lu, P.H., Cao, C. (2018). Itraconazole-induced inhibition on human esophageal cancer cell growth requires AMPK activation. Mol. Cancer Ther., 17(6), 1229-1239.

[120]. Liang, G., Liu, M., Wang, Q., Shen, Y., Mei, H., Li, D., Liu, W. (2017). Itraconazole exerts its anti-melanoma effect by suppressing Hedgehog, Wnt, and PI3K/mTOR signaling pathways. Oncotarget, 8(17), 28510.

[121]. Hara, M., Nagasaki, T., Shiga, K., Takeyama, H. (2016). Suppression of cancerassociated fibroblasts and endothelial cells by itraconazole in bevacizumab-resistant gastrointestinal cancer. Anticancer Res., 36(1), 169-177.

[122]. Aftab, B.T., Dobromilskaya, I., Liu, J.O., Rudin, C.M. (2011). Itraconazole inhibits angiogenesis and tumor growth in non-small cell lung cancer. Cancer Res., 71(21), 67646772 .

[123]. Wang, J., Xu, X., Zhou, R., Guo, K. (2015). Effects of itraconazole plus doxorubicin on proliferation and apoptosis in acute myeloid leukemia cells. Chin. J. Cancer, 95(4), 299305.

[124]. Sari, I.N., Phi, L.T.H., Jun, N., Wijaya, Y.T., Lee, S., Kwon, H.Y. (2018). Hedgehog signaling in cancer: a prospective therapeutic target for eradicating cancer stem cells. Cells, 7(11), 208.

[125]. Tsubamoto, H., Ueda, T., Inoue, K., Sakata, K., Shibahara, H., Sonoda, T. (2017). Repurposing itraconazole as an anticancer agent. Oncology letters, 14(2), 1240-1246.

[126]. Peyton, L.R., Gallagher, S., Hashemzadeh, M. (2015). Triazole antifungals: a review. Drug. Today (Barc), 51(12), 705-718.

[127]. Choi, S.H., Lee, S.Y., Hwang, J.Y., Lee, S.H., Yoo, K.H., Sung, K.W., Koo, H.H., Kim, Y.J. (2013). Importance of voriconazole therapeutic drug monitoring in pediatric cancer patients with invasive aspergillosis. Pediatr. Blood Cancer, 60(1), 82-87.

[128]. Pham, A.N., Bubalo, J.S., Lewis, J.S. (2016). Comparison of posaconazole serum concentrations from haematological cancer patients on posaconazole tablet and oral suspension for treatment and prevention of invasive fungal infections. Mycoses, 59(4), 226-233.

[129]. Takahashi, H., Abe, M., Sugawara, T., Tanaka, K., Saito, Y., Fujimura, S., Shibuya, M., Sato, Y. (1998). Clotrimazole, an imidazole antimycotic, is a potent inhibitor of angiogenesis. Jpn. J. Clin. Oncol., 89(4), 445-451.

[130]. Khalid, M.H., Shibata, S., Hiura, T. (1999). Effects of clotrimazole on the growth, morphological characteristics, and cisplatin sensitivity of human glioblastoma cells in vitro. J. Neurosurg., 90(5), 918-927.

[131]. Adinolfi, B., Carpi, S., Romanini, A., Da Pozzo, E., Castagna, M., Costa, B., Martini, C., Olesen, S.P., Schmitt, N., Breschi, M.C., Nieri, P., Fogli, S. (2015). Analysis of the antitumor activity of clotrimazole on A375 human melanoma cells. Anticancer Res., 35(7), 3781-3786.

[132]. McDonald, A.J., Curt, K.M., Patel, R.P., Kozlowski, H., Sackett, D.L., Robey, R.W., Gottesman, M.M., Bates, S.E. (2019). Targeting mitochondrial hexokinases increases efficacy of histone deacetylase inhibitors in solid tumor models. Exp. Cell Res., 375(2), 106-112.

[133]. Dong, C., Yang, R., Li, H., Ke, K., Luo, C., Yang, F., Shi, X.N., Zhu, Y., Liu, X., Wong, M.H., Lin, G., Wang, X., Leung, K.S., Kung, H.F., Chen, C., Lin, M.C. (2017). Econazole nitrate inhibits PI3K activity and promotes apoptosis in lung cancer cells. Sci. Rep., 7(1), 17987. 
[134]. Rochlitz, C.F., Damon, L.E., Russi, M.B., Geddes, A., Cadman, E.C. (1988). Cytotoxicity of ketoconazole in malignant cell lines. Cancer Chemother. Pharmacol., 21(4), 319-322.

[135]. Lu, C.T., Leong, P.Y., Hou, T.Y., Kang, Y.T., Chiang, Y.C., Hsu, C.T., Lin, Y.D., Ko, J.L., Hsiao, Y.P. (2019). Inhibition of proliferation and migration of melanoma cells by ketoconazole and Ganoderma immunomodulatory proteins. Oncol. Lett., 18(1), 891-897. 